\title{
Article/Artigo
}

\section{Hepatitis B virus infection in children, adolescents, and their relatives: genotype distribution and precore and core gene mutations}

\author{
Infecção pelo vírus da hepatite B em crianças, adolescentes e seus familiares: distribuição dos \\ genótipos e mutações no gene pré-core e core
}

\section{Adriana Parise Compri ${ }^{1}$, Irene Miura ${ }^{2}$, Gilda Porta ${ }^{2}$, Marcilio Figueiredo Lemos ${ }^{1}$, Cláudia Patara Saraceni ${ }^{1}$ and Regina Célia Moreira ${ }^{1}$}

\begin{abstract}
Introduction: The objectives of this study were evaluate hepatitis B virus (HBV) serological markers in children and adolescents followed up at the Child Institute of the Hospital das Clínicas, Faculdade de Medicina de São Paulo, Universidade de São Paulo; identify chronic HBV carriers and susceptible individuals in the intrafamilial environment; characterize HBV genotypes; and identify mutations in the patients and household contacts. Methods: Ninetyfive hepatitis B surface antigen-positive children aged $<19$ years and 118 household contacts were enrolled in this study. Commercial kits were used for the detection of serological markers, and PCR was used for genotyping. Results: Hepatitis B e antigen ( $\mathrm{HBeAg}$ ) was detected in $66.3 \%$ (63/95) of cases. Three of the $30 \mathrm{HBeAg}$-negative and anti-HBeAg-positive patients presented with precore mutations and 11 presented with mutations in the basal core promoter (BCP). Genotype A was identified in $39(43.8 \%)$ patients, genotype D in $45(50.6 \%)$, and genotype $\mathrm{C}$ in 5 (5.6\%). Of the 118 relatives, 40 were chronic HBV carriers, 52 presented with the anti-HBc marker, 19 were vaccinated, and 7 were susceptible. Among the relatives, genotypes $\mathrm{A}, \mathrm{D}$, and $\mathrm{C}$ were the most frequent. One parent presented with a precore mutation and 4 presented with BCP mutations. Conclusions: Genotypes A and D were the most frequent among children, adolescents, and their relatives. The high prevalence of $\mathrm{HBV}$ in the families showed the possibility of its intrafamilial transmission.
\end{abstract}

Keywords: Hepatitis B. Genotype. Mutation. Vertical transmission. Horizontal transmission.

\section{RESUMO}

Introdução: Os objetivos deste estudo foram: avaliar os marcadores sorológicos nas crianças e adolescentes acompanhadas no Instituto da Criança do Hospital das Clínicas, Faculdade de Medicina da Universidade de São Paulo (HC-FMUSP); identificar portadores crônicos do VHB e indivíduos suscetíveis no ambiente intrafamiliar; caracterizar o genótipo do VHB; observar a presença de cepas mutantes entre os pacientes e familiares estudados. Métodos: Noventa e cinco crianças e adolescentes positivas para o antígeno de superfície do vírus da Hepatite B (AgHBs), menores de 19 anos, e 118 familiares foram envolvidos neste estudo. Foram utilizados kits comerciais para a pesquisa dos marcadores sorológicos e a PCR foi utilizada para genotipagem. Resultados: O antígeno e do vírus da hepatite $\mathrm{B}(\mathrm{AgHBe})$ foi detectado em 66,3\% (63/95) dos casos. Três dos 30 pacientes AgHBe negativo e anti-HBe positivo apresentaram mutação na região pré-core e 11 na região BCP.Em $39(43,8 \%)$ pacientes, foi identificado o genótipo A, 45 (50,6\%)o genótipo D e cinco (5,6\%) o genótipo C. Dos 118 familiares estudados, 40 eram portadores crônicos do VHB, 52 tinham marcador sorológico de contato prévio e sete eram suscetíveis. Dentre os familiares AgHBs positivos, os genótipos $\mathrm{A}, \mathrm{D}$ e $\mathrm{C}$ foram os mais frequentes. Um familiar apresentou mutação na região pré-core $\mathrm{e}$ quatro apresentaram mutação na região do $\mathrm{BCP}$. Conclusões: Os genótipos $\mathrm{A}$ e $\mathrm{D}$ foram os mais frequentes dentre as crianças adolescentes e seus familiares. Alta frequência do VHB nos familiares mostrou a possibilidade de transmissão intrafamiliar.

Palavras-chaves: Hepatite B. Genótipo. Mutação. Transmissão vertical. Transmissão horizontal.

1. Laboratório de Hepatites Virais, Instituto Adolfo Lutz, São Paulo, SP. 2. Instituto da Criança, Hospital das Clínicas, Faculdade de Medicina, Universidade de São Paulo, São Paulo, SP.

Address to: Dra. Adriana Parise Compri. Centro de Virologia/Núcleo de Doenças Sexuais e Sanguíneas /IAL. Av. Doutor Arnaldo 355, 01246-902 São Paulo, SP, Brasil.

Phone: 5511 3068-2911

e-mail: adri_parise@yahoo.com

Received in 28/04/2011

Accepted in 08/09/2011

\section{INTRODUCTION}

Hepatitis B continues to be an important public health problem worldwide and more than 350 million people are estimated to be chronic carriers, with the occurrence of 1 million deaths yearly ${ }^{1}$.

Parenteral and sexual exposure seem to be the major routes of viral dissemination, and vertical transmission may occur from chronic hepatitis $B$ virus (HBV)-carrier mothers to their children either in utero or around the time of delivery. The risk of mother-to-infant transmission is $85-90 \%$ if the mother is positive for the hepatitis $\mathrm{B}$ surface antigen (HBsAg) and hepatitis B e antigen ( $\mathrm{HBeAg}$ ), but infection is still possible even if the mother is HBeAg-negative ${ }^{2}$. Children who are not infected at birth are still at risk from infected households and community contacts, especially in subpopulations in which HBV infection is prevalent ${ }^{2}$. Horizontal transmission has been reported in regions of the world where the prevalence of hepatitis B infection is high, e.g., Southeast Asia, Middle East, and subSaharan Africa ${ }^{2,3}$.

The genetic variability of HBV is based on variations in the sequence of protein S. Okamoto et al. proposed a classification system for the complete viral sequence, and $\mathrm{HBV}$ is currently classified into 8 genotypes $(\mathrm{A}-\mathrm{H})^{4}$. Genotypes $\mathrm{A}, \mathrm{B}, \mathrm{C}, \mathrm{D}$, and $\mathrm{F}$ have already been described in Brazil ${ }^{5}$. Mutations inhibiting the synthesis of $\mathrm{HBeAg}$ (i.e., in the precore and core regions) reportedly aggravate liver disease and cause fulminant hepatitis in children and adults ${ }^{6}$.

The objectives of this study were: I) evaluate HBV serological markers in children and adolescents followed up at the Child Institute of the Hospital das Clínicas, Faculdade de Medicina da Universidade de São Paulo (HC-FMUSP); II) identify chronic carriers of $\mathrm{HBV}$ and susceptible individuals in the intrafamilial environment; III) characterize HBV genotypes; and IV) identify mutations in the patients and household contacts. 


\section{METHODS}

\section{Population}

The study population consisted of children and adolescents aged $<19$ years who were seen at the Hepatology Unit of the Child Institute, HC-FMUSP, and who were HBsAg-positive for $>6$ months. In addition, the household contacts of these patients were invited to participate in this study. Blood samples were collected from the patients and their relatives between 1999 and 2004 after signing an informed consent form.

\section{Serological assays}

Serological markers (HBsAg and total anti-HBc) were identified using a commercially available enzyme-linked immunosorbent assay (ELISA) (Diasorin ${ }^{\mathrm{rx}}$; Saluggia Mark, Vercelli, Italy).

\section{Polymerase chain reaction}

A nested polymerase chain reaction (PCR) was carried out as described by Kaneko et al., with some modifications ${ }^{7-9}$. The $S$ region was amplified according to the protocol reported by Sitnik et al. for the identification of the HBV genotype ${ }^{10}$.

\section{Sequencing reaction}

For the characterization of viral strains, the samples were sequenced using PCR according to the method of Sanger et al., by using the ABI Prism BigDye ${ }^{\text {Ts }}$ Terminator Kit (PE Applied Biosystems, Foster City, CA, USA) in an automatic ABI Prism 377 sequencer ${ }^{11}$. Genotyping and basal core promoter $(\mathrm{BCP})$ and precore mutations were analyzed by comparison with the sequences of different HBV genotypes deposited in GenBank, by using the EditSeq and MegAlign programs of the DNAstar package (LaserGene, Inc.).

\section{Viral load}

Viral load was quantified in all HBsAg- and HBeAg-positive samples, employing the COBAS AMPLICOR HBV MONITOR test (Roche Molecular Systems, Inc., Branchburg, NJ, USA). Samples with a viral load higher than the detection limit were diluted in human HBV-negative plasma.

\section{Statistical analysis}

For statistical analysis, the Kruskal-Wallis test was used. A p-value $<0.05$ was considered significant.

\section{Ethical considerations}

This project was approved by the Committees Scientific of the Division of Medical Biology (BM (04/04), for Ethics in Research at the Instituto Adolfo Lutz (CEPIAL) and Ethics of the Child Institute, HC-FMUSP, according to resolution no. 196/96 on research involving human beings published by the National Council of the Brazilian Ministry of Health (1996). It is noteworthy that all samples were collected only after the completion of the Free and Informed Consent form.

\section{RESULTS}

\section{Serology}

Ninety-five HBsAg-positive children and adolescents were enrolled in this study; 53 (55.8\%) were male and 42 (44.2\%) were female. Serological analysis showed that $63(66.3 \%)$ patients were $\mathrm{HBeAg}$-positive and 30 (93.7\%) of the 32 negative samples were positive for anti-HBe (Table 1).

The relatives of 85 of the patients enrolled in this study could be contacted, for a total of 118 individuals. These serological data are shown in Table 2.

TABLE 1 - Frequency of hepatitis B virus serological markers in children and adolescents seen at the Child Institute, Hospital das Clínicas, Faculdade de Medicina da Universidade de São Paulo, according to age.

\begin{tabular}{|c|c|c|c|c|c|c|c|c|c|c|c|c|}
\hline \multirow[b]{2}{*}{ Age (years) } & \multirow[b]{2}{*}{$\mathbf{n}$} & \multirow[b]{2}{*}{$\%$} & \multirow{2}{*}{\multicolumn{2}{|c|}{$\begin{array}{c}\text { Male } \\
\mathbf{n}\end{array}$}} & \multirow{2}{*}{\multicolumn{2}{|c|}{$\begin{array}{c}\text { Female } \\
\mathbf{n}\end{array}$}} & \multicolumn{2}{|c|}{ Anti-HBc (total) } & \multicolumn{2}{|c|}{ HBeAgB } & \multicolumn{2}{|c|}{ Anti-HBe } \\
\hline & & & & & & & $\mathbf{n}$ & $\%$ & $\mathbf{n}$ & $\%$ & $\mathbf{n}$ & \%* \\
\hline $0-4$ & 23 & 24.2 & & 10 & & 13 & 23 & 100.0 & 16 & 69.5 & 7 & 30.4 \\
\hline $10-14$ & 26 & 27.4 & & 14 & & 12 & 26 & 100.0 & 18 & 69.2 & 6 & 23.0 \\
\hline $15-19$ & 6 & 6.3 & & 2 & & 4 & 6 & 100.0 & 3 & 50.0 & 3 & 50.0 \\
\hline Total & 95 & 100.0 & 53 & 55.8 & 42 & 44.2 & 93 & 97.9 & 63 & 66.3 & 30 & 93.7 \\
\hline
\end{tabular}

Anti-HBc total: total antibodies against the hepatitis B core antigen; HBeAg: hepatitis B e antigen; anti-HBe: antibodies against the hepatitis B e antigen. ${ }^{*}$ The presence of anti-HBe was only determined in HBeAg-negative samples.

TABLE 2 - Frequency in relatives according to the degree of kinship and serological markers.

\begin{tabular}{|c|c|c|c|c|c|c|c|c|c|c|c|}
\hline \multirow[b]{3}{*}{ Relationship } & \multirow[b]{3}{*}{$\mathbf{N}$} & \multicolumn{10}{|c|}{ Serological markers } \\
\hline & & \multicolumn{2}{|c|}{ HBsAg } & \multicolumn{2}{|c|}{ Anti-HBc (total) } & \multicolumn{2}{|c|}{ HBeAg } & \multicolumn{2}{|c|}{ Anti-HBe } & \multicolumn{2}{|c|}{ Anti-HBs } \\
\hline & & $\mathbf{n}$ & $\%$ & $\mathbf{n}$ & $\%$ & $\mathbf{n}$ & $\%$ & $\mathbf{n}$ & $\%$ & $\mathbf{n}$ & $\%$ \\
\hline Father & 28 & 7 & 25.0 & 22 & 78.6 & 2 & 7.1 & 4 & 14.3 & 15 & 53.6 \\
\hline Sibling & 25 & 1 & 4.0 & 13 & 52.0 & 0 & 0.0 & 0 & 0.0 & 13 & 52.0 \\
\hline Others & 7 & 2 & 28.5 & 3 & 42.8 & 0 & 0.0 & 1 & 14.3 & 2 & 28.5 \\
\hline Total & 118 & 40 & 33.9 & 90 & 76.3 & 15 & 12.7 & 21 & 17.8 & 52 & 44.1 \\
\hline
\end{tabular}

HBsAg: hepatitis B surface antigen; anti-HBc total: total antibodies against the hepatitis B core antigen; HBeAg: hepatitis B e antigen; anti-HBe: antibodies against the hepatitis B e antigen; anti-HBs: antibodies against the hepatitis B surface antigen; N: number of individuals. 


\section{Genotypes}

The $\mathrm{S}$ region could be amplified in samples from 89 (93.7\%) patients. Genotype A was identified in 39 (43.8\%) patients, genotype $\mathrm{D}$ in 45 (50.6\%), and genotype $\mathrm{C}$ in 5 (5.6\%). Genotype $\mathrm{D}$ showed a significantly higher viral load in children $\left(6.09 \times 10^{7} \mathrm{IU} / \mathrm{mL} ; \mathrm{p}=0.01\right)$

The $S$ region of the HBV genome could be amplified and genotyped in 27 samples from $\mathrm{HBsAg}$-positive relatives. The distribution of the genotypes was as follows: genotype A, 13 (48.1\%) samples; genotype D, 12 (44.4\%); and genotype C, 2 (7.5\%). Table 3 shows the genotypes of the patients and their relatives.

TABLE 3 - Frequency in children, adolescents, and relatives according to viral load.

\begin{tabular}{|c|c|c|c|c|c|c|}
\hline \multirow[b]{2}{*}{ Viral load (IU/mL) } & \multicolumn{2}{|c|}{$\begin{array}{l}\text { Children and } \\
\text { adolescents }\end{array}$} & \multicolumn{2}{|c|}{ Relatives } & \multicolumn{2}{|c|}{ Total } \\
\hline & $\mathbf{n}$ & $\%$ & n & $\%$ & $\mathbf{n}$ & $\%$ \\
\hline$<60$ & 6 & 6.7 & 1 & 3.8 & 7 & 6.0 \\
\hline $60-10^{2}$ & 4 & 4.5 & 3 & 11.1 & 7 & 6.0 \\
\hline $10^{2}-10^{4}$ & 18 & 20.2 & 7 & 25.9 & 25 & 21.5 \\
\hline $10^{4}-10^{6}$ & 3 & 3.4 & 5 & 18.5 & 8 & 7.0 \\
\hline $10^{6}-10^{8}$ & 19 & 21.4 & 5 & 18.5 & 24 & 20.7 \\
\hline$>10^{8}$ & 39 & 43.8 & 6 & 22.2 & 45 & 38.8 \\
\hline Total & 89 & 100.0 & 27 & 100.0 & 116 & 100.0 \\
\hline
\end{tabular}

\section{Mutations}

Among the 95 children and adolescents studied, 30 were $\mathrm{HBsAg}$ /anti-HBe-positive and $\mathrm{HBeAg}$-negative, and the precore and core regions could be amplified in 21 (70\%). Of these, 13 patients harbored mutations, while 8 did not. Among the 21 relatives who participated in the study and had compatible profiles for the investigation of core and precore mutations, the samples of 9 individuals could be amplified and 4 (44.4\%) harbored mutations.

The mean viral load was significantly higher among HBeAgpositive individuals $\left(5.56 \times 10^{7} \mathrm{IU} / \mathrm{mL}\right)$ compared with $\mathrm{HBeAg}$ negative individuals $\left(1.51 \times 10^{5} \mathrm{IU} / \mathrm{mL} ; \mathrm{p} \leq 0.00001\right)$. No significant difference was found between the distribution of the 2 genotypes and viral load $(\mathrm{p}=0.0177)$.

\section{DISCUSSION}

Chronic hepatitis B infection is a global health problem, and transmission from mother to infant is a major route of acquisition throughout the world. Infections acquired in childhood are responsible for the largest majority of chronic HBV infections, with its attendant complications of cirrhosis and hepatocellular carcinoma ${ }^{2}$.

Some studies have demonstrated the relationship between HBV genotypes and the clinical course of the infection; however, these data are still scarce and inconsistent, and the number of eligible patients is still small, especially with respect to childhood data. Therefore, the present study was of extreme importance since it was possible to analyze a large number of serum samples from children and adolescents who were chronic hepatitis B carriers. In studies conducted on children from Argentina and Belgium, the number of patients was $\sim 25^{12,13}$. In addition, it was possible to investigate most of the household contacts of the patients, and we were only unable to contact the relatives of 10 patients. Analysis of the frequency of
HBsAg-positive children and adolescents according to age showed that most children with chronic $\mathrm{HBV}$ infection were aged 0-14 years, and only $6.3 \%$ of the population studied were adolescents. This fact might be related to the characteristics of the health service in which the study was carried out, which mainly cares for children.

Among the 118 familial contacts studied, 58 were mothers and 30 of them were chronic carriers of HBV. This finding indicates the importance of serological screening for HBV during pregnancy, since this route of transmission is associated with a high (90\%) risk of chronic HBV infection and a low incidence of acute symptomatic hepatitis. Moreover, 13 of these 58 mothers were HBeAg-positive. This is an extremely relevant finding since the risk of vertical transmission increases with increasing maternal viral load, when the levels of $\mathrm{HBsAg}$ are high, and in the presence of $\mathrm{HBeAg}^{2}$.

Twenty-two fathers were found to be anti-HBc total-positive, and these individuals might be responsible for the intrafamilial transmission of the virus. The same may apply to the other 32 relatives, with 16 (50\%) of them presenting with this marker, supporting the hypothesis for the intrafamilial dissemination of HBV.

Low vaccine coverage was observed among the relatives of chronic HBV carriers (19/118). This finding is a matter of concern since, despite the availability of the vaccine within the public health network for all children at birth, vaccine coverage is still low for adolescents and patients who are at an increased risk, especially among adolescents ${ }^{14}$. Thus, adolescent vaccination should be encouraged since the vaccine is the most important and efficient tool for the prevention of hepatitis $\mathrm{B}$, especially for adolescents at a high risk of infection.

The present results are similar to those reported in the few studies published in Brazil, i.e., genotypes A and D were the most frequent among adolescents. Genotype $\mathrm{C}$ was detected in families of Asian origin, in agreement with studies showing the occurrence of genotype $\mathrm{C}$ in Asian countries ${ }^{15,16}$. Sitnik et al., studying the prevalence of HBV genotypes in chronic carriers from different regions of Brazil, also found genotype $\mathrm{C}$ in individuals of Asian origin ${ }^{5,17}$.

Our results agree with other Brazilian studies ${ }^{18-22}$ showing that genotypes $\mathrm{A}$ and $\mathrm{D}$ were the most frequent in the general population. It is interesting to observe that viral load was higher in genotype $\mathrm{D}$ carriers than in the other carriers. This increases the possibility of the transmission of this strain, especially in countries with a high prevalence of this genotype, like Brazil.

A genotype discrepancy between individuals of 2 families was observed. In family 1 , the patients had genotype $\mathrm{A}$, whereas the father had genotype D. However, it was not possible to amplify the $S$ region from the mother's sample, which could have elucidated this difference. In family 2, divergence between the patient's and mother's genotypes could not be elucidated using only serological evidence since the father had been vaccinated. In this case, both the mother and the child could have been infected by different sources at different times.

Only 2 patients had the G1896A mutation and 1 patient had mutations in the precore and core regions (G1899A) as well as in the BCP, all of which were characterized as genotype $\mathrm{D}$. The same genotype was observed in a relative who harbored mutations in the precore and core regions.

In the present study, a high percentage of precore and core mutations were observed in genotype $\mathrm{D}$ strains. The low prevalence of mutations in genotype A strains was expected, as reported by other 
investigators ${ }^{5,19,23}$. Mutations are more frequent in the $\mathrm{BCP}$ region than in the precore and core regions. This might be related to the fact that $\mathrm{BCP}$ mutations are associated with genotypes that present with a cytosine at position 1858 , as is the case for genotype $\mathrm{A}^{24}$.

Our study also showed that HBeAg-positive individuals presented with the highest viral load. The determination of viral load, together with $\mathrm{HBeAg}$ detection, could also contribute to the choice of drugs and length of hepatitis B treatment. These data agree with those reported by other authors ${ }^{22}$.

A low frequency of precore and core mutations were observed in the population studied due to the high frequency of genotype A. The rate of susceptible individuals was still high, confirming the need for preventive and control measures for $\mathrm{HBV}$ infection, especially for individuals sharing the same intrafamilial environment in view of the high propagation rate of this virus.

\section{CONFLICT OF INTEREST}

The authors declare that there is no conflict of interest.

\section{FINANCIAL SUPPORT}

Fundação de Amparo a Pesquisa de São Paulo (FAPESP) 06/59974-8.

\section{REFERENCES}

1. Assis SB, Valente JG, Fontes CJF, Gaspar AMC, Souto FJD. Prevalência de marcadores do virus da hepatite $B$ em crianças de 3 a 9 anos em um município da Amazônia brasileira. Rev Panam Salud Publica 2004; 15:26-34.

2. Broderick AL, Jonas MM. Hepatitis B in children. Semin Liver Dis 2003; 23:59-68.

3. Yao GB. Importance of perinatal versus horizontal transmission of hepatitis B virus in China. Gut 1996; 38 (suppl 2):539-542.

4. Okamoto H, Tsuda F, Sakugawa H, Sastrosoewignjo RI, Imai M, Miyakawa Y, et al. Typing hepatitis B virus by homology in nucleotide sequence: comparison of surface antigen subtypes. J Gen Virol 1988; 69:2575-2583.

5. Sitnik R, Pinho JRR, Bertolini DA, Bernardini AP, Silva LC, Carrilho FJ. Hepatitis $B$ virus genotypes and precore and core mutants in Brazilian patients. J Clin Microbiol 2004; 42:2455-2460.

6. Papatheodoridis GV, Hadziyannis SJ. Diagnosis and management of pre-core mutant chronic hepatitis B. J Viral Hepatitis 2001; 8:311-321.

7. Kaneko S, Feinstone SM, Miller RH. Rapid and sensitive method for the detection of serum hepatitis B virus DNA using the polymerase chain reaction technique. J Clin Microbiol 1989a; 27:1930-1933.

8. Kaneko S, Miller RH, Feinstone SM, Unoura M, Kobayashi K, Hattori N, et al. Detection of serum hepatitis B virus DNA in patients with chronic hepatitis using the polymerase chain reaction assay. Proc Natl Acad Sci USA 1989b; $86: 312-316$

9. Pinho JRR, Santos CA, Gonzales CLM, Bassit L, Barreto CC, Sáez-Alquezar H, et al. Detection of hepatitis B virus DNA by the polymerase chain reaction in anti-HBe positive chronic hepatitis B patients. Rev Inst Trop São Paulo 1993; 35:515-520.

10. Sitnik R. Padronização de reações de sequenciamento para caracterização do vírus da hepatite B: genótipos, subtipos, mutantes na região pré-core, promotor basal do core, epitopo "a" e resistência aos antivirais. [Thesis]. [São Paulo]: Faculdade de Medicina da Universidade de São Paulo; 2002. 119 p.

11. Sanger F, Nichlen S, Coulson AR. DNA sequencing with chain terminating inhibitors. Proc Natl Acad Sci 1977; 74:5463-5465.

12. Mbayed VA, Lopez JL, Telenta PFS, Palacios G, Badia L, Ferro A, et al Distribution of hepatitis $B$ virus genotypes in two different pediatric populations from Argentina. J Clin Microbiol 1998; 3362-3365.

13. Liu HF, Sokal E, Goubau P. Wide variety of genotypes and geographic origins of hepatitis B virus in Belgian children.J Pediatr Gastroenterol Nutr 2005; 32:274-277.

14. Ferreira CT, Silveira TR. Viral hepatitis prevention by immunization. J Pediatr 2006; 82:S55-S66

15. Chu CJ, Hussain M, Lok AS. Hepatitis B virus genotype B is associated with earlier $\mathrm{HBeAg}$ seroconversion compared with hepatitis B virus genotype C. Gastorenterology 2002; 122:1756-1762.

16. Orito E, Mizokami M. Hepatitis B virus genotypes and hepatocellular carcinoma in Japan. Intervirology 2003; 46:408-412.

17. Clemente CM, Carrilho FJ, Pinho JRR, Ono-Nita SK, Da Silva LC, Moreira RC, et al. A phylogenetic study of hepatitis B virus in chronically infected Brazilian patients of Western and Asian descent. J Gastroenterol 2009; 44:568-576.

18. Carrilho FJ, Moraes CR, Pinho JRR, Moreira RC, Bertolini DA, Mello IM, et al Hepatitis B virus infection in haemodialysis centers from Santa Catarina State, Southern Brazil: predictive factors for infection and molecular epidemiology. Hepatology 2001; 34(pt. 4): 612A.

19. Conde SRSS, Móia LJP, Barbosa MSB, Amaral ISA, Miranda ECBM, Soares MCP, et al. Prevalência de genótipos e de mutantes pré-core A1896 do vírus da hepatite $B$ e suas implicações na hepatite crônica, em uma população da Amazônia oriental. Rev Soc Bras Med Trop 2004; 37 (supl II):33-39.

20. Viana S, Paraná R, Moreira RC, Compri AP, Macedo V. High prevalence of hepatitis B virus and hepatitis D virus in the Western Brazilian Amazon. Am J Trop Med Hyg 2005; 73:808-814.

21. Alcade R, Melo FL, Nishiya A, Ferreira SC, Langhi Júnior MD, Fernandes SS et al. Distribution of hepatitis B virus genotypes and viral load levels chronically infected patients in São Paulo City. Rev Inst Med Trop S Paulo 2009; 51:269-272.

22. Tonetto PA, Gonçalves NS, Fais VC, Vigani AG, Gonçalves ES, Feltrin A, et al. Hepatitis B virus: molecular genotypes and $\mathrm{HBeAg}$ serological status among HBV-infected patients in the southeast of Brazil. BMC Infect Dis 2009; 9:149.

23. Castro L, Niel C, Gomes SA. Low frequency of mutations in the core promote and precore regions of hepatitis $\mathrm{B}$ virus in anti-HBe positive Brazilians carriers. BMC Microbiology 2001; 1:10-18.

24. Kramvis A, Kew MC. The core promoter of hepatitis B virus. J Viral Hepatitis 1999; 6:415-427. 